\title{
Isolation of high quality RNA from soil-grown Ilex paraguariensis roots suitable for next- generation sequencing and gene expression analyses
}

\author{
Edgardo H. Avico ${ }^{1}$, Raúl M. Acevedo ${ }^{1}$, Pablo I. Calzadilla², Oscar A. Ruiz², Pedro A. Sansberro ${ }^{1, *}$ \\ ${ }^{1}$ Laboratorio de Biotecnología Aplicada y Genómica Funcional. Instituto de Botánica del Nordeste (CONICET), \\ Facultad de Ciencias Agrarias, Universidad Nacional del Nordeste, Sargento Cabral 2131, CC: 209, W3402BKG, \\ Corrientes, Argentina \\ ${ }^{2}$ Unidad de Biotecnología 1. Instituto de Investigaciones Biotecnológicas-Instituto Tecnológico de Chascomús \\ (UNSAM-CONICET). Av. Intendente Marino Km 8,200 CC: 164. B7130IWA, Chascomús, Buenos Aires, \\ Argentina
}

*Corresponding author: sansber@agr.unne.edu.ar

\begin{abstract}
Extraction of high quality RNA is a prerequisite for downstream application in functional genomics analyses. However, the extraction and purification of pure nucleic acids from root tissues is generally difficult due to the high concentration of carbohydrates and secondary metabolites. Furthermore, the presence of enzymatic inhibitors such as fulvic and humic acids can also negatively affect extraction quality, when extracting from clay soil-grown roots. In this work, total RNA was extracted from soil-grown roots of Ilex paraguariensis using four commercially available kits: Spectrum ${ }^{\mathrm{TM}}$, RNeasy ${ }^{\circledR}$, TRI Reagent ${ }^{\circledR}$, and SV Total RNA Isolation System. Spectral measurement and electrophoresis were used to demonstrate RNA quality and quantity. The Spectrum ${ }^{\mathrm{TM}}$ and RNeasy ${ }^{\circledR}$ protocols provided the highest quantity and quality of RNA; however, the former revealed superior extraction performance. Consequently, total RNA was extracted from the roots of non-stressed and drought-stressed plants using the Spectrum ${ }^{\mathrm{TM}}$ method and six RNA-seq libraries were prepared from polyA + mRNAs by means of TruSeq mRNA library construction protocol to convert RNA to complementary DNA (cDNA). More than 80 million raw read sequences were obtained from each condition with an average read length of $150 \mathrm{bp}$. The yield and quality of the total RNA were consistently high and the RNA could be used for further analyses as demonstrated by cDNA library construction, RT-PCR, and transcriptome sequencing. Thus, Spectrum ${ }^{\mathrm{TM}}$ method can be used to isolate high quality RNA from roots of normal and drought stressed I. paraguariensis plants.
\end{abstract}

Keywords: Clay soil; dehydration; drought; Ilex paraguariensis; RNA isolation; RNA-seq; root tissues, woody plant. Abbreviations: PCA_principal component analysis; qRT-PCR_quantitative real-time PCR; RIN_RNA integrity number;

\section{Introduction}

Ilex paraguariensis St. Hil. (Aquifoliaceae) is a shadetolerant tree cultured in northeastern Argentina, southeastern Brazil, and Paraguay. Its leaves and young shoots are used to prepare a tea-like infusion which has stimulant properties and various medicinal benefits (Heck and De Mejia, 2007). Drought and high temperatures during the growing season impose stress on this species, to which it acclimates by triggering a cascade of transcriptomic responses that modify cell metabolism (Acevedo et al., 2016). Stress conditions can affect crop yield, gene expression studies, as well as gene identification and functional characterization based on RNA sequencing are important tools for plant breeding.

Current high-throughput genomics analysis requires the isolation of high-quality RNA with high integrity and free of proteins, genomic DNA, and enzyme inhibitors. Integrity is particularly important for quantitative real-time PCR (qRTPCR) analysis, while purity is essential for reproducibility (Fleige and Pfaffl, 2006). Unfortunately, the presence of carbohydrates and secondary metabolites can interfere with isolation (Ghawana et al., 2011). In effect, tissue of woody plant contains high level of polyphenols, flavonoids and other compounds which bind and precipitate with nucleic acids. This situation becomes more problematic in case of stressedtissues, in which a high level of secondary metabolites accumulates as part of the plant defense mechanism to tolerate the adverse environmental conditions (Shinozaki et al., 2015). For this reason, the isolation of suitable RNA from trees is considered more difficult than it is for herbaceous plants (Morante-Carriel et al., 2014). In particular, I. paraguariensis tissues present high levels of polyphenols and other secondary metabolites (Filip et al., 2001). Moreover, isolation from root extracts is even more difficult due to their high fiber content, elevated concentration of storage compounds, enzyme inhibitors and contaminants in the soil, in which the roots are grown (Das et al., 2013). Additionally, some soil substances such as humic and fulvic acids can strongly inhibit DNA polymerase (Matheson et al., 2010). To the best of our knowledge, no method has been established for the effective isolation of total RNA from the roots of soilgrown Ilex paraguariensis plant. Our aim was to evaluate four commercially available kits, specifically the Spectrum ${ }^{\mathrm{TM}}$ Plant Total RNA Kit (Sigma), RNeasy ${ }^{\circledR}$ Plant Mini Kit 
(Qiagen), TRI Reagent ${ }^{\circledR}$ (Molecular Research Center), and SV Total RNA Isolation System (Promega), for their ability to extract total RNA from roots. The Spectrum ${ }^{\mathrm{TM}}$ kit showed the highest RNA yield and quality among the four, which was tested on roots from non-stressed and drought-stressed plants. Quality of the isolated RNA for downstream application was analyzed by determining the RNA integrity number.

\section{Results and discussion}

\section{Comparison of RNA extraction kits}

Four RNA extraction kits were evaluated on Ilex paraguariensis roots to identify the best method for isolating a large quantity of high quality RNA for transcriptome sequencing. The quality of total RNA analyzed by agarose gel electrophoresis is presented in Fig 1. Intact bands corresponding to $28 \mathrm{~S}$ and $18 \mathrm{~S}$ rRNA were clearly visible in RNA samples obtained from TRI Reagent ${ }^{\circledR}$, Spectrum $^{\mathrm{TM}}$ and RNeasy ${ }^{\circledR}$ but not from SV kit. The sharpness of the ribosomal RNA bands indicated that there was no RNA degradation. Bands of lower molecular weight were also observed corresponding to $5 \mathrm{~S}$ rRNA. The samples provided different band intensities, indicating differences in total RNA quantity. No DNA contamination was visible in any of the samples.

Concentration and purity of the RNA samples calculated from $\mathrm{A}_{260}, \mathrm{~A}_{280}$ and $\mathrm{A}_{230}$ are shown in Fig 3. Although, all tested kits yielded detectable RNA from well-watered roots, but the Spectrum ${ }^{\mathrm{TM}}$ method provided the highest total RNA, ranged from 53.9 to $75.9 \mathrm{ng} \cdot \mathrm{mg}^{-1} \mathrm{DW}$, whereas RNeasy ${ }^{\circledR}$ and TRI Reagent methods produced lower amounts, ranged from $44.2 \pm 16.4$ to $22.4 \pm 3.8 \mathrm{ng} \cdot \mathrm{mg}^{-1} \mathrm{DW}$, respectively (Fig. $3 \mathrm{a}$ ). The SV kit was ineffective for root RNA isolation and this result complies with those obtained previously in other recalcitrant species (Zamboni et al., 2008). The absorbance ratio $\mathrm{A}_{260} / \mathrm{A}_{280}$ is generally used to determine protein contamination of a nucleic acid sample and its expected value should be somewhere around 2.1 for high quality RNA with minimum impurities (Gallagher and Desjardins, 2006). In this way, the ratios of isolated RNA from Spectrum ${ }^{\mathrm{TM}}$ and RNeasy ${ }^{\circledR}$ kits were in the same ranges and close to the optimum value indicating trace amounts of proteins (Fig. 3b). Meanwhile, the absorbance ratio $\mathrm{A}_{260} / \mathrm{A}_{230}$ indicates the presence of organic contaminants, such as secondary metabolites, soil substances, and reagents (Reck et al., 2015). Samples with $\mathrm{A}_{260} / \mathrm{A}_{230}$ ratios below 1.8 are considered to have a significant amount of these contaminants that will interfere with downstream applications (Sambrook, 2001). Our results have shown that the RNA isolated with commercial kits which included bind-wash-elution methods (Spectrum $^{\mathrm{TM}}$, RNeasy ${ }^{\circledR}$, and SV) had lower impurities (Fig. $3 \mathrm{c})$. In contrast, the direct extraction method using phenol and guanidine isothiocyanate liquid phase separation (TRI Reagent) was less effective to control the impurities present in the sample since the $A_{260} / A_{230}$ ratio was lesser than 0.5. Finally, yield and quality were analyzed with PCA to test the efficiency of RNA extraction kits on root tissues harvested from soil-grown plant. Fig $3 d$ shows that the Spectrum ${ }^{\mathrm{TM}}$ kit has the best performance like combined yield and purity. Additionally, to evaluate possible downstream applications, we performed RT-PCR analysis of the $\beta$-tubulin gene of $I$. paraguariensis (Acevedo et al., 2013). RNA samples obtained from Spectrum ${ }^{\mathrm{TM}}$, RNeasy ${ }^{\circledR}$ and TRI Reagent amplified the $\beta$-tubulin gene (data not shown).

\section{De novo transcriptome sequencing}

According with our previous results, the Spectrum ${ }^{\mathrm{TM}}$ protocol was chosen to evaluate the RNA quality for transcriptome sequencing of non-stressed and drought-stressed roots. RIN calculated from the profiles demonstrated the quality assessments of the RNA for subsequent de novo transcriptome sequencing (Fig. 4). The RIN analysis indicated that the integrity of RNA from drought-stressed plants (RIN=7.2, 7.7, 8.1 out of 10) were lower than those from non-stressed samples $(\mathrm{RIN}=8.1,8.1,8.6$ out of 10$)$. This data reflects that RNA isolated from roots subjected to drought might be more susceptible to RNA degradation than those isolated from non-stressed plants. However, de novo sequencing of RNA samples from roots grown under water deficit and well-watered conditions yielded a total of 87.5 and 84.7 million raw read sequences from 3 libraries, respectively (Fig. 5). The average length of each paired-end read was $150 \mathrm{bp}$. This high-throughput data generated in this study can later be used to assemble a de novo transcriptome using Trinity software (Grabherr et al., 2011).

\section{Materials and methods}

\section{Plant material and sample collections}

Two-year-old Ilex paraguariensis plants were grown in $4 \mathrm{~L}$ pots filled with lateritic soil and subjected to controlled environmental conditions $\left(27 \pm 1 / 22 \pm 2{ }^{\circ} \mathrm{C}\right.$, day / night; $14 \mathrm{~h}$ photoperiod; $\left.420 \mu \mathrm{mol} \cdot \mathrm{m}^{-2} \cdot \mathrm{s}^{-1} \mathrm{PPFD} ; 50-55 \% \mathrm{RH}\right)$. Plants were watered regularly during the acclimatization period. Thereafter, water was withheld until the soil water potential $\left(\Psi_{\text {soil }}\right)$ reached -2 MPa to induce drought stress. Both nonstressed $\left(\Psi_{\text {soil }}=\sim-0.04 \mathrm{MPa}\right)$ and drought-stressed plants were uprooted carefully for the collection of roots. The collected samples were rinsed with tap water, immediately immersed in liquid nitrogen and stored at $-70{ }^{\circ} \mathrm{C}$ until further processing.

\section{Extraction and purification of total RNA}

Total RNA was extracted from the adventitious roots of nonstressed plants by means of the commercial kits Spectrum ${ }^{\mathrm{TM}}$ Plant Total RNA Kit (Spectrum ${ }^{\mathrm{TM}}$, Sigma), RNeasy ${ }^{\circledR}$ Plant Mini Kit (RNeasy ${ }^{\circledR}$, Qiagen), TRI Reagent ${ }^{\circledR}$ (TRI Reagent ${ }^{\circledR}$, Molecular Research Center), and SV Total RNA Isolation System (SV, Promega). Around 100-150 mg root tissue was ground to a fine powder in liquid nitrogen. Extractions were performed by triplicate according to each manufacturer's protocol (Fig. 2). For Spectrum ${ }^{\mathrm{TM}}$, RNeasy ${ }^{\circledR}$ and TRI Reagent $^{\circledR}$, DNA contamination was avoided by including a digestion step with DNase (Invitrogen ${ }^{\mathrm{TM}}$ RNase-free DNase I Thermo Fisher Scientific). Total RNA integrity was verified by resolving $10 \mu 1$ of each extraction on a native $1.2 \%(\mathrm{w} / \mathrm{v})$ agarose gel stained with ethidium bromide. The bands were visualized under UV light and the images were documented using the gel documentation unit GelDoc-It ${ }^{\circledR}$ (UVP). Meanwhile, total RNA purity was assessed by determining the absorbance of the samples at 230, 260, 280, and $320 \mathrm{~nm}$ (background absorption) using a spectrophotometer (SmartSpec $^{\mathrm{TM}}$ Plus, Bio-Rad). Extractions with an absorbance ratio $\mathrm{A}_{260} / \mathrm{A}_{280}$ higher than 1.8 were quantified

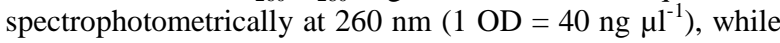
samples with an absorbance ratio $\mathrm{A}_{260} / \mathrm{A}_{280}$ lower than 1.8 were estimated by applying the following correction (Glasel 1995):

$$
\begin{aligned}
\% \text { Nucleic acid }= & (11.16[\text { A260/A280] }-6.32) /(2.16 \\
& -[\text { A260/A280] })
\end{aligned}
$$




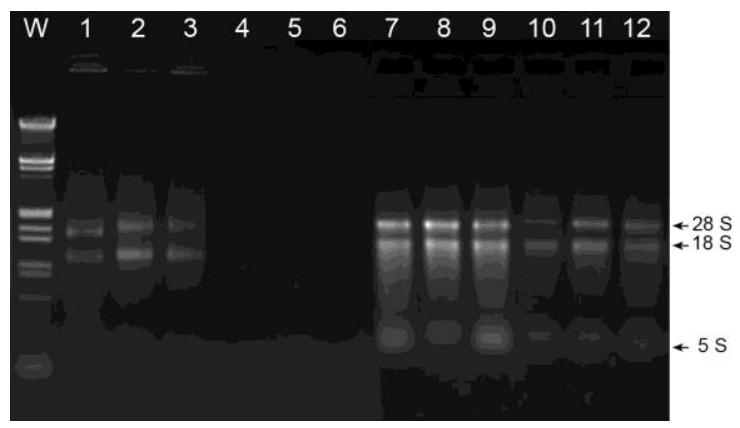

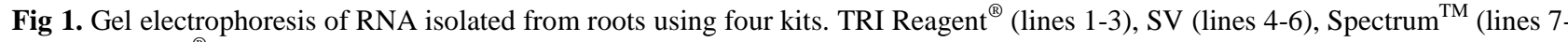
9), and RNeasy ${ }^{\circledR}$ (lines 10-12) kits.

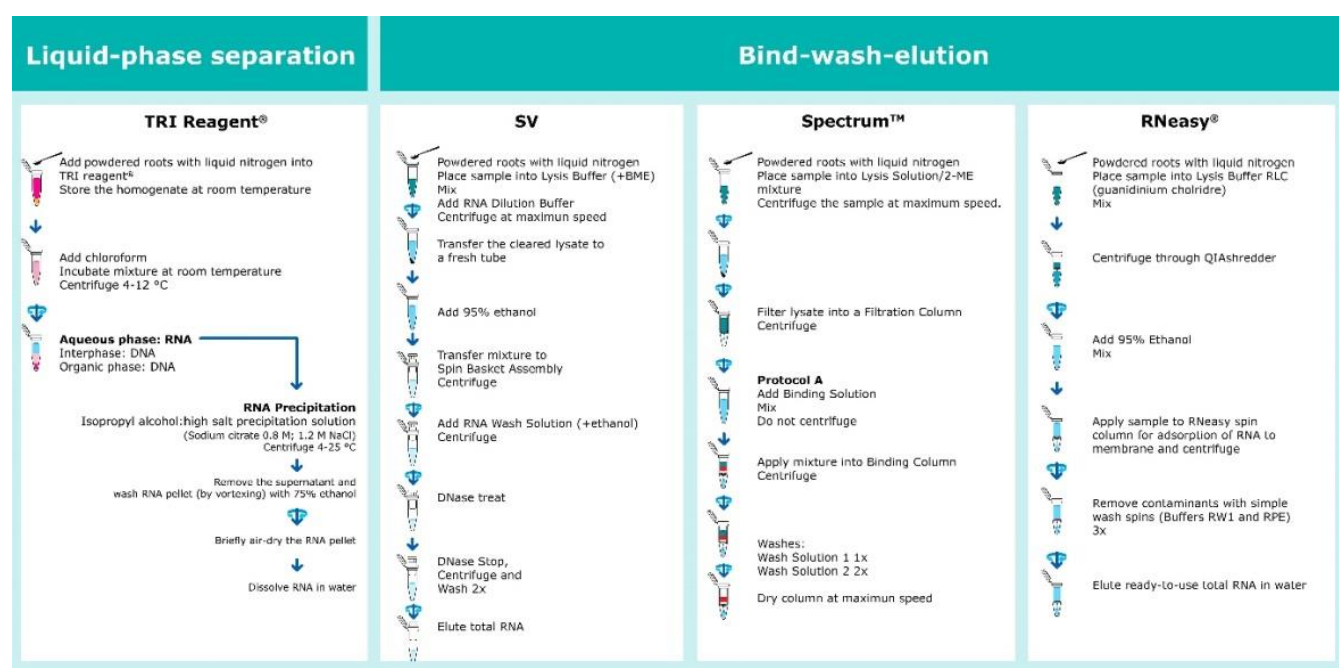

Fig 2. Schematic representation of the protocols used for the isolation of root RNA collected from soil-grown plants. For Spectrum ${ }^{\mathrm{TM}}$ RNeasy $^{\circledR}$ and TRI Reagent ${ }^{\circledR}$, DNA contamination was avoided by including a digestion step with DNase as described in materials and methods.

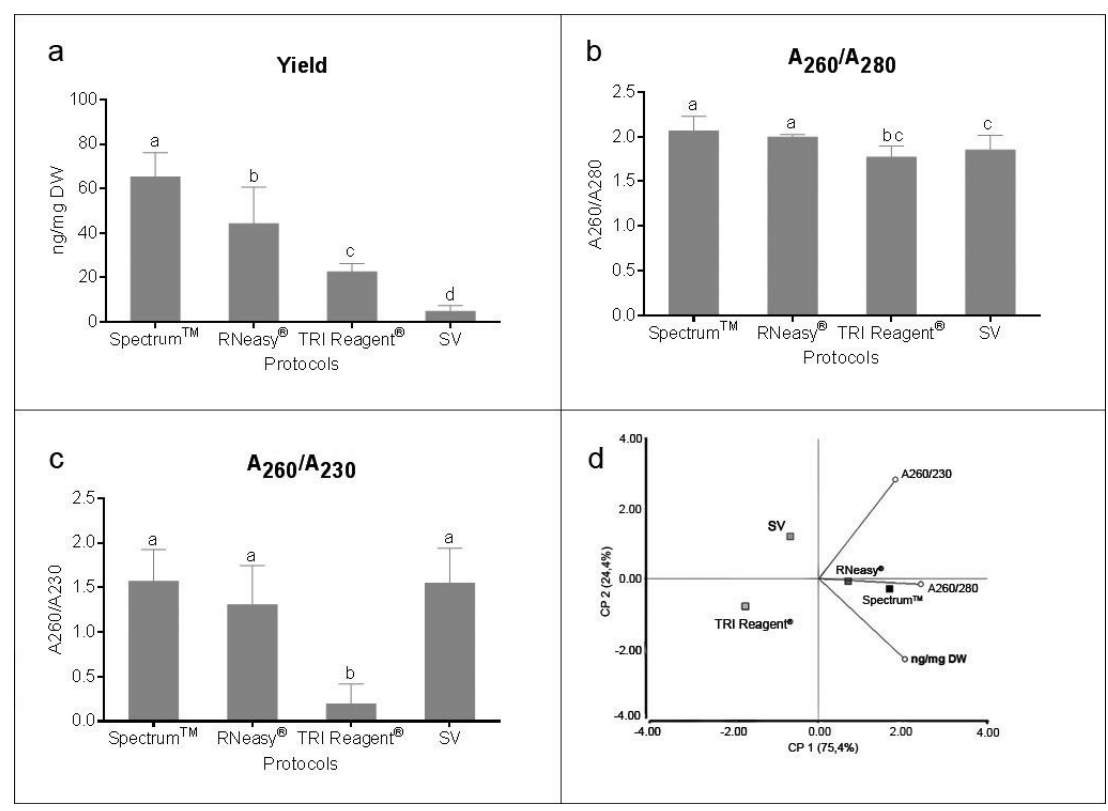

Fig 3. Quantity and quality of root RNA isolated from I. paraguariensis using four methods. (a) Total RNA yields. (b-c) Absorbance ratios $\mathrm{A}_{260} / \mathrm{A}_{280}$ and $\mathrm{A}_{260} / \mathrm{A}_{230}$ indicate presence of proteins and secondary metabolites impurities, respectively. (d) Principal Components Analysis Biplot relating quality and yield. Means with similar letters do not differ significantly $(P=0.01)$. 

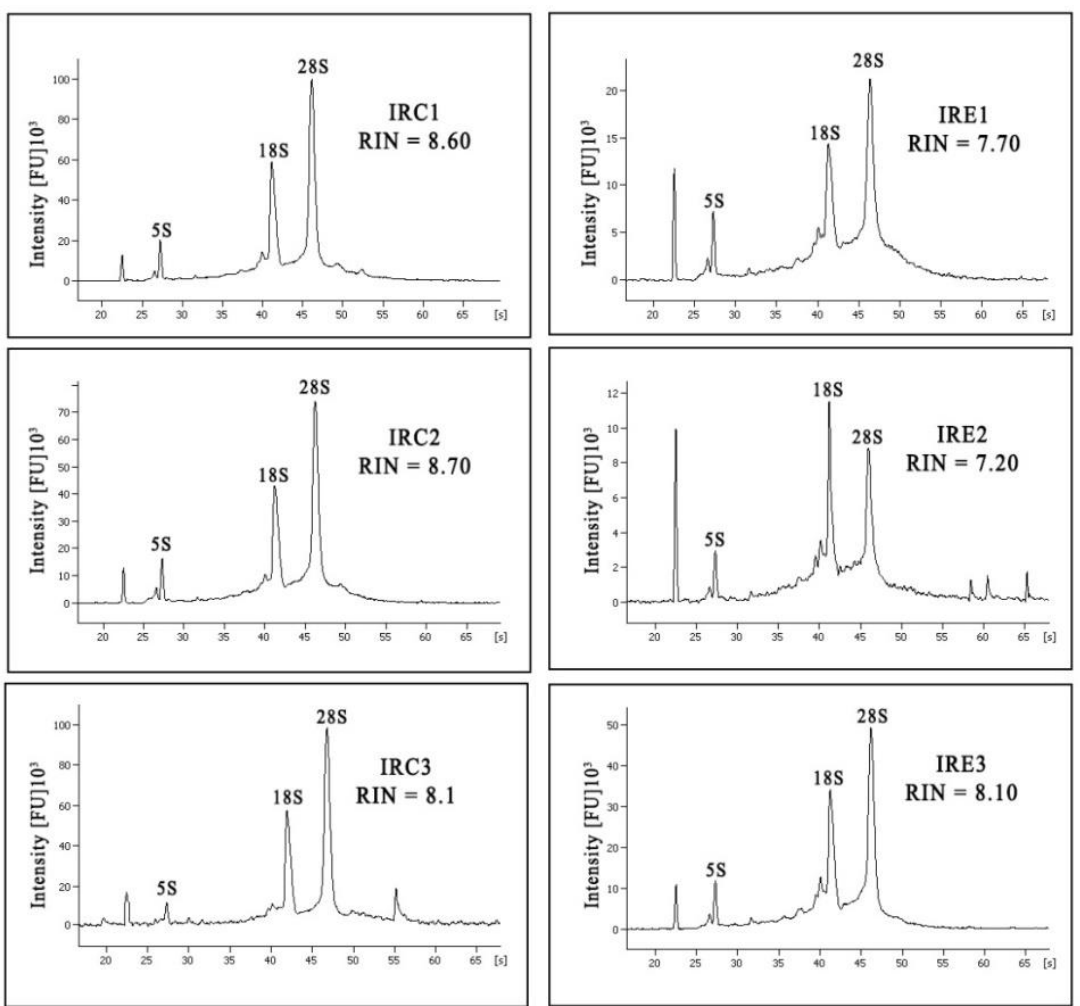

Fig 4. Electropherograms of RNA isolated from root tissues. RNA was extracted from non-stressed (left) and drought-stressed (right) plants with Spectrum ${ }^{\mathrm{TM}}$ Plant Total RNA kit. Three biological replicates were used for each treatment. RNA integrity number (RIN) values are indicated within the graph. The $28 \mathrm{~S}$ and $18 \mathrm{~S}$ and $5 \mathrm{~S}$ peaks were marked.

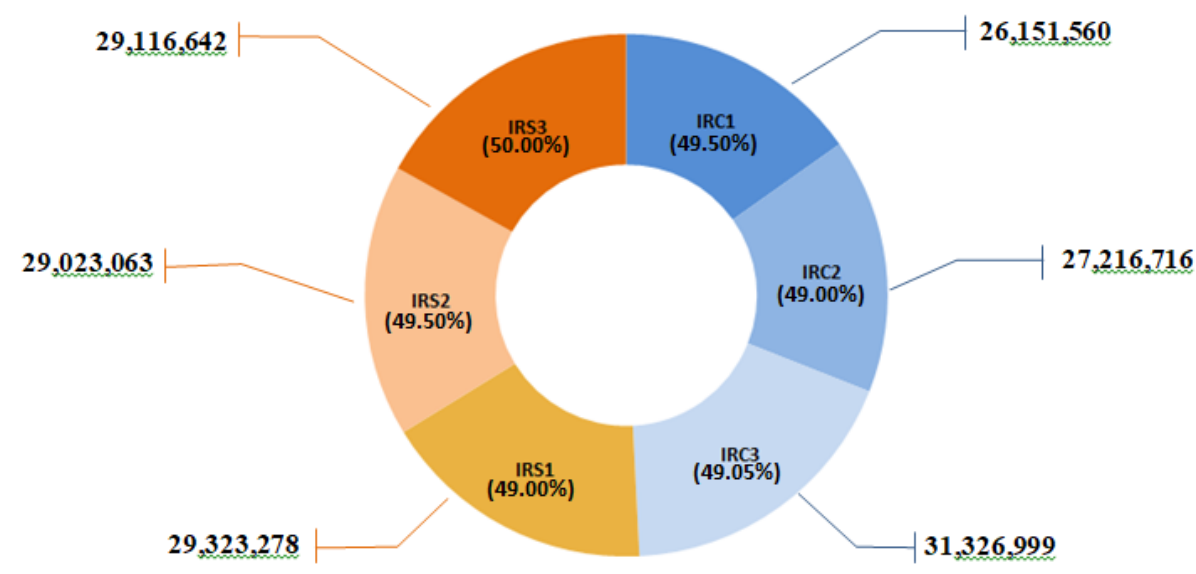

Fig 5. De novo transcriptome sequencing of RNA isolated from I. paraguariensis roots. Number of paired-ends reads from plants subjected to non-stressed (IRC) and drought-stressed (IRS) conditions. Raw reads data represented the total read count after adaptor eliminations (filtered). Citocine-guanine contents are shown in parentheses. Total RNA was extracted by using Spectrum ${ }^{\mathrm{TM}}$ Plant Total RNA kit.

\section{cDNA synthesis and real-time PCR analysis}

First-strand cDNA was synthesized from $1 \mu \mathrm{g}$ of total RNA from each sample according to the protocol of SuperScript ${ }^{\circledR}$ II Reverse Transcriptase (Thermo Fisher Scientific). Quantitative RT-PCR reactions were prepared with SYBR Green PCR Master Mix (Applied Biosystems). The $I$. paraguariensis $\beta$-tubulin gene with the primer sequences 5'CTGGAGAAGGGATGGATGAA-3' (forward) and
5'-GGCATCCTGATATTGCTGGT-3' (reverse) was amplified as the reference gene (Acevedo et al. 2013). qRTPCR was carried out on an Applied Biosystems 7500 RealTime PCR System using SYBR Premix according to the protocol. The thermocycler program consisted of an initial denaturation $\left(95{ }^{\circ} \mathrm{C}\right.$ for $10 \mathrm{~min}$ ), followed by 40 cycles of $95{ }^{\circ} \mathrm{C}$ for $15 \mathrm{~s}$ and $60{ }^{\circ} \mathrm{C}$ for $1 \mathrm{~min}$. Two biological replicates were amplified in triplicate. 


\section{RIN analysis and RNA-sequencing}

RIN analysis for RNA-sequencing was achieved from RNA isolations using the Spectrum ${ }^{\mathrm{TM}}$ kit from either non-stressed and/or drought stressed plants. Quality control was performed by the system Agilent 2100 Bioanalyzer with a RNA pico/nano Chip platform (Agilent Technologies) and evaluated by interpretation of the RIN value in the range 110 (fully degraded RNA - intact RNA).

Six RNA-seq libraries were prepared from polyA+ mRNAs using TruSeq mRNA library construction protocol (Illumina). High-throughput pair-end $(2 \times 150 \mathrm{bp})$ sequencing was performed on a HiSeq 1500 platform (Illumina). The quality of raw read data was accessed by FastQC program (http://www.bioinformatics.babraham.ac.uk/projects/fastqc). Trimmomatic program (Bolger et al. 2014) was used to remove adapters from the raw reads.

\section{Experimental design and statistical analysis}

The experiment was repeated three times by performing three biological units. The data sets were subjected to the ShapiroWilk test for normality $(\alpha=0.05)$ and were statistically analyzed by ANOVA (GraphPad version 7.0). Tukey's multiple comparison test was used to compare differences among the treatments. A value of $P=0.01$ was used to assess statistical significance. Principal component analysis (PCA) was performed with Infostat ${ }^{\circledR}$.

\section{Conclusion}

The Spectrum $^{\mathrm{TM}}$ Plant Total RNA kit (Sigma) was demonstrated to be the most effective method for extracting a large amount of high quality RNA required for transcriptome sequencing of $I$. paraguariensis roots, even from waterstressed plants.

\section{Acknowledgements}

This work was supported by grants from Agencia Nacional de Promoción Científica y Tecnológica (PICT 2014-1246), Secretaría General de Ciencia y Técnica- Universidad Nacional del Nordeste (PI A001/14), and Establecimiento Las Marías S.A. (Gdor. Virasoro, Corrientes, Argentina). OAR and PAS are members of the Research Council of Argentina (CONICET). EHA and PIC received CONICET scholarships. RMA is Professor of the Universidad Nacional del Nordeste (UNNE).

\section{Conflict of Interest}

The authors declare that they have no conflict of interest.

\section{Author contributions}

Conceived and designed the experiments: EHA, OAR and PAS. Performed the experiments: EHA, RMA and PIC. Analyzed the data: EHA, MHA and PAS. Written the manuscript: PAS.

\section{References}

Acevedo RM, Maiale SJ, Pessino SC, Bottini R, Ruiz O, Sansberro P (2013) A succinate dehydrogenase flavoprotein subunit-like transcript is upregulated in Ilex paraguariensis leaves in response to water deficit and abscisic acid. Plant Physiol Bioch. 65:48-54.

Acevedo RM, Ruiz O, Sansberro P (2016) Transcriptome expression profiling in response to drought stress in Ilex paraguariensis leaves. Plant Omics. 9:334-343.

Bolger AM, Lohse M, Usadel B (2014) Trimmomatic: a flexible trimmer for Illumina sequence data. Bioinformatics. 30:2114-20.

Das A, Saha D, Mondal TK (2013) An optimized method for extraction of RNA from tea roots for functional genomics analysis. Indian J Biotechnol. 12:129-132.

Filip R, Lopez P, Giberti G, Coussio J, Ferraro G (2001) Phenolic compounds in seven South American Ilex species. Fitoterapia. 72:774-778.

Fleige S, Pfaffl MW (2006) RNA integrity and the effect on the real-time qRT-PCR performance. Mol Aspects Med. 27:126139.

Gallagher SR, Desjardins PR (2008) Quantitation of DNA and RNA with absorption and fluorescence spectroscopy. Curr Protoc Protein Sc. 76:3D:A.3D.1-A.3D.21.

Ghawana S, Paul A, Kumar H,Kumar A, Singh H, Bhardwaj PK, Rani A, Singh RS, Raizada J, Singh K and Kumar S (2011) An RNA isolation system for plant tissues rich in secondary metabolites. BMC Res Notes. 4:85-89.

Glasel JA (1995) Validity of nucleic acid purities monitored by $260 \mathrm{~nm} / 280 \mathrm{~nm}$ absorbance ratios. Biotechniques. 18:62-63.

Heck CI, De Mejia EG (2007) Yerba mate tea (Ilex paraguariensis): a comprehensive review on chemistry, health implications, and technological considerations. J Food Sci. 72:138-151.

Grabherr MG, Haas BJ, Yassour M, Levin JZ, Thompson DA, Amit I, Adiconis X, Fan L, Raychowdhury R, Zeng Q, Chen Z, Mauceli E, Hacohen N, Gnirke A, Rhind N, di Palma F, Birren BW, Nusbaum C, Lindblad-Toh K, Friedman N, Regev A (2011) Full-length transcriptome assembly from RNA-seq data without a reference genome. Nat Biotechnol. 29:644-52

Matheson CD, Gurney C, Esau N, Lehto R (2010) Assessing PCR inhibition from humic substances. Open Enzym Inhib J. 3:38-45.

Morante-Carriel J, Sellés-Marchart S, Martínez-Márquez A, Martínez-Esteso MJ,Luque I, Bru-Martínez R (2014) RNA isolation from loquat and other recalcitrant woody plants with high quality and yield. Anal Biochem. 452:46-53.

Reck M, Tomasch J, Deng Z,Jarek M, Husemann P, Wagner Döbler I (2015) Stool metatranscriptomics: a technical guideline for mRNA stabilisation and isolation. BMC Genomics. 16:1

Sambrook JR (2001) Molecular cloning. A laboratory manual, Third ed. CSHL Press, New York.

Shinozaki K, Uemura M, Bailey-Serres J, Bray EA, Weretilnyk E (2015) Plant responses to abiotic stress. In: Buchanan BB, Gruissem W, Russell LJ (ed) Biochemistryand molecular biology of plants, 2nd edn. Wiley, Chichester, UK. Pp:10511100.

Zamboni A, Pierantoni L, De Franceschi P (2008) Total RNA extraction from strawberry tree (Arbutus unedo) and several other woody-plants. IFOREST. 1:122-125. 